\title{
The Law of Similarity and Designing High-Performance Composites
}

\author{
A. Tolstoy ${ }^{(凶)}$, V. Lesovik, E. Glagolev, and L. Zagorodniuk \\ Belgorod State Technological University named after V.G. Shukhov, \\ Belgorod, Russia \\ tad56@mail.ru
}

\begin{abstract}
The increasing requirements for the quality of building products and constructions condition the importance of developing new ways of controlling the processes of shaping the structure of composite materials. This paper considers the aspects of dealing with the tasks of designing high-performance powder composites factoring in the law of similarity.
\end{abstract}

Keywords: Law of similarity $\cdot$ High-performance materials $\cdot$ Powder concrete Technogenic raw materials

\section{Introduction}

In our days, erecting special-purpose buildings and structures with complex design, as well as the so-called unique buildings, calls for using high-performance powder concrete, which composition differs from the composition of traditional normal concrete in the increased proportion of cement, higher fineness of grain, complex composition and increased dispersity of aggregate (Bazhenov et al. 2007; Tolstoy et al. 2018a, b; Lesovik et al. 2015). The role of each of the source materials, as well as that of the mechanism of interaction between them, increases manifold, with fundamental concepts of the law of similarity can explain the nature of the processes that occur.

The theoretical foundation for designing high-quality composites is a new crossdisciplinary scientific school: geonics (geomimetics), which employs the results of studies of natural processes and rocks to create building materials of the future (Lesovik 2014; Elistratkin and Kozhukhova 2018; Dmitrieva et al. 2018). This allowed to develop a system for designing powder concrete using raw materials that were specially prepared through geological processes, i.e. they are genetically activated (Tolstoy et al. 2014).

A separate school is further distinguished: crystal energy science, the science about the modern approaches to estimating the quantitative indicators of the properties of materials and explaining the processes of hydrate formation (Lesovik and Evtushenko 2002).

The criteria of applicability of mineral components should be: abundance, accessibility, cost, constant composition (Fig. 1). 


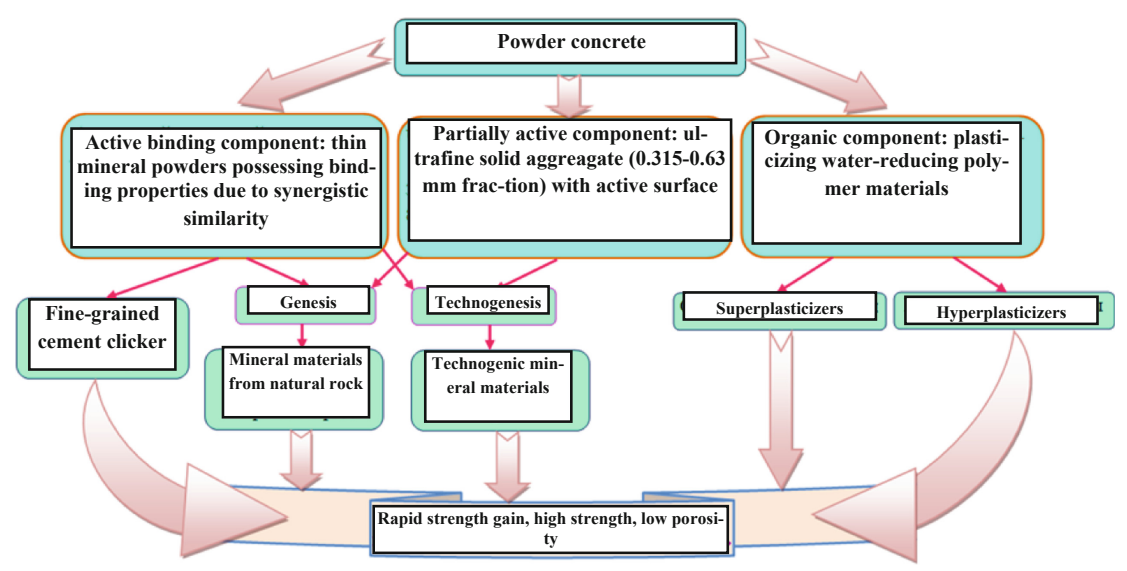

Fig. 1. Types of raw materials for making powder concrete

Here it is necessary to use the "experience" of geological processes, for example, high-performance siltstones that are similar to powder concrete in their strength and other properties. To create a strong and lasting composite of powder concrete, it is necessary to ensure the reliable physical, mechanical and performance characteristics of the material structure taking into account all energy parameters of all the substances involved, as well as the compliance of other properties. This structure should be similar to natural materials in terms of the main properties and genesis.

\section{Methods and Approaches}

The experiments involved mineral admixtures containing the aluminate and carbonate components, as well as off-the-shelf polymer ones: Melflux 2651, Melment, and finely ground quartzite sandstone, a by-product rock from the Kursk Magnetic Anomaly (KMA).

\section{Results and Discussion}

At the moment there is no unified approach to the technique of producing highperformance compositions. Some researchers address the issue from the perspective of technological mechanics, other approaches consider the rheological properties of the system, optimization of grain size composition, and the relation between the optimal structure and extreme properties of components (the "law of gauge" by I.A. Rybiev (Rybev 1999)).

The proposed methods of controlling the formation of structure in curing systems of powder mixes with technogenic components allow to achieve the composite strength of 80-100 MPa (Table 1). 
Table 1. Comparative figures of normal concrete and powder concrete

\begin{tabular}{l|l|l}
\hline \multirow{2}{*}{ Parameter } & \multicolumn{2}{|l}{ Values } \\
\cline { 2 - 3 } & Normal concrete & Powder concrete \\
\hline Average density, $\mathrm{kg} / \mathrm{m}^{3}$ & $2200-2500$ & 2300 \\
\hline Compressive strength, MPa & $10-50$ & 97.5 \\
\hline Water retention capacity, \% & $78-80$ & 90 \\
\hline Strength-density ratio & 0.17 & 0.36 \\
\hline Water resistance grade. W & $2-4$ & 4 \\
\hline Freeze-thaw resistance grade, $\mathrm{F}$ & $50-150$ & 300 \\
\hline Wear capacity, $\mathrm{kg} / \mathrm{m}^{2}$ & $0.7-0.8$ & 0.36 \\
\hline Shrinkage & No fractures \\
\hline Thermal conductivity ratio, $\mathrm{W} /(\mathrm{m} \mathrm{K})$ & $0.8-1.2$ & 1.29 \\
\hline
\end{tabular}

A feasible foundation can be represented by the method of estimating the composition of high-density concrete taking into account the law of similarity of properties (Tolstoy et al. 2018a, b).

Dense structure of powder concrete is characterized by a virtually complete absence of pores and microfractures. It was possible to implement this by using the adjusted composition of the curing mass, introducing the necessary number of fine-grained technogenic components, their densest packing, and the self-compacting effect of curing.

Study of the micrographs of the curing compositions revealed the following:

- the microstructure of the cement rock obtained through intergrinding possesses higher homogeneity than that obtained through separate grinding of components;

- growth of needle-shaped crystals that permeate the volume of the material's structure was detected;

- dense neogeneses are present near the aggregate grains;

\section{Conclusions}

This way, introducing the theory of geonics (geomimetics), particularly the law of similarity, allows to obtain high-performance powder concretes, all components of which possess a high adhesion and similar deformation and thermal characteristics. The first attempt to test this law allowed to obtain composites with the maximum compressive strength of up to $100 \mathrm{MPa}$.

Acknowledgements. The work has been fulfilled within the project Federal Target Program of Research and Development on "Priority Development Fields of science and technology sector in Russia for 2014-2020", unique project number is RFMEFI58317X0063. 


\section{References}

Bazhenov IM, Demianova VS, Kalashnikov VI (2007) Modifitcirovannye vysokoprochnye betony [Modified high-performance concretes], ASV, Moscow, $368 \mathrm{p}$

Dmitrieva TV, Strokova VV, Bezrodnykh AA (2018) Influence of the genetic features of soils on the properties of soil-concretes on their basis. Constr Mater Prod 1(1):69-77

Elistratkin MYu, Kozhukhova MI (2018) Analysis of the factors of increasing the strength of the non-autoclave aerated concrete. Constr Mater Prod 1(1):59-68

Lesovik VS (2014) Geonika (Geomimetika) [Geonics (Geomimetics)]. Primery realizatcii v stroitelnom materialovedenii [Examples of application in building materials science]. Bulletin of BSTU named after V.G. Shoukhov, Belgorod, $206 \mathrm{p}$

Lesovik VS, Zagorodniuk LK, Chulkova IL, Tolstoy AD, Volodchenko AA (2015) Srodstvo struktur, kak teoreticheskaia osnova proektirovaniia kompozitov budushchego [Similarity of structures as a theoretical foundation of designing the composites of the future]. Stroitelnye materialy [Building materials], no 9, pp 18-22

Lesovik BC, Evtushenko EI (2002) Stabilizatciia svoistv stroitelnykh materialov na osnove tekhnogennogo syria [Stabilizing the properties of building materials on the basis of technogenic raw materials]. Izvestiia VUZov [Bul. HEIs]. 12:40-44

Rybev IA (1999) Otkrytie zakona stvora i vzaimosviaz ego s zakonom kongruentcii v stroitelnom materialovedenii [Discovering the gauging law and its relation to the law of congruence in building materials science]. Stroitelnye materialy [Build Mater] 12:30-31

Tolstoy AD, Lesovik VS, Milkina AS (2018a) Osobennosti struktury betonov novogo pokoleniia $\mathrm{s}$ primeneniem tekhnogennykh materialov [Specifics of the structure of new-generation concretes using technogenic materials]. Russ Automob Highw Ind J Sect III Constr Arch. 15(4, 62):588-595

Tolstoy AD, Lesovik VS, Kovaleva IA (2014) Organomineralnye vysokoprochnye dekorativnye kompozitcii [Organic and mineral high-performance decorative compositions]. Bull BSTU Named After V.G. Shoukhov 5:67-69

Tolstoy AD, Lesovik VS, Glagolev ES, Krymova AI (2018b) Synergetics of hardening construction systems. In: IOP conference series: materials science and engineering, vol 327, p 032056. https://doi.org/10.1088/1757-899x/327/3/032056

Open Access This chapter is licensed under the terms of the Creative Commons Attribution 4.0 International License (http://creativecommons.org/licenses/by/4.0/), which permits use, sharing, adaptation, distribution and reproduction in any medium or format, as long as you give appropriate credit to the original author(s) and the source, provide a link to the Creative Commons license and indicate if changes were made.

The images or other third party material in this chapter are included in the chapter's Creative Commons license, unless indicated otherwise in a credit line to the material. If material is not included in the chapter's Creative Commons license and your intended use is not permitted by statutory regulation or exceeds the permitted use, you will need to obtain permission directly from the copyright holder.

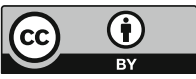

